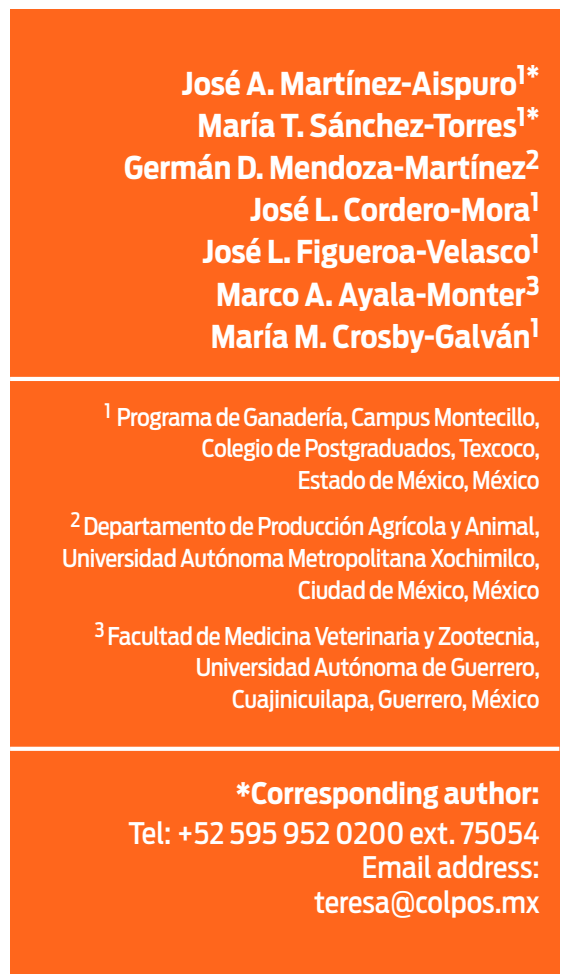

Accepted: 2018-11-22

Published: 2019-02-05

Additional information and declarations can be found on page 7

(c) Copyright 2018 Jose A. Martinez-Aispuro et al.

open access $\boldsymbol{\gamma}$

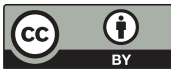

Distributed under Creative Commons CC-BY 4.0

\section{Addition of calcium propionate to finishing lamb diets}

\section{Abstract}

Calcium ( $\mathrm{Ca}$ ) propionate can be added to ruminant diets as a glucogenic substrate. However, due to its hypophagic effect, it is necessary to establish the optimal dose that can be used to replace grains in finishing diets for lambs. Therefore, the objective of this study was to assess the effect of four concentrations of Ca propionate in lamb diets on productive performance and rumen fermentation. Thirty two Hampshire $\mathrm{x}$ Suffolk lambs (23.82 $\pm 0.40 \mathrm{~kg}$ initial body weight), distributed in a completely randomized design, were given a diet with four concentrations of Ca propionate $\left(\mathrm{g} \mathrm{kg}^{-1}\right): 0,10,20$ or $30 \mathrm{~g}$, for 42 days. The results were tested for linear or quadratic responses. The final weight, average daily gain and feed: gain ratio showed quadratic responses $(P \leq 0.01)$. The optimal dose was established at $13.77 \mathrm{~g} \mathrm{~kg}^{-1} \mathrm{DM}$. Addition of Ca propionate did not affect variables related to rumen fermentation $(\mathrm{pH}$, total volatile fatty acids, acetate, butyrate or rumen ammonia- $\mathrm{N} ; \mathrm{P} \geq 0.05$ ). Nonetheless, glucose and propionate concentrations showed a quadratic response $(P \leq 0.05)$. The highest concentrations of propionate in rumen were observed with $15.14 \mathrm{~g} \mathrm{~kg}^{-1} \mathrm{DM}$. Results indicate that Ca propionate can be included in a dose of up to $13.77 \mathrm{~g} \mathrm{~kg}^{-1} \mathrm{DM}$ in feedlot rations, to attain best lamb performance.

Keywords: volatile fatty acids; glucose; metabolizable energy; calcium propionate; lambs.

\section{Cite this as:}

Martinez-Aispuro JA, Sánchez-Torres MT, Mendoza-Martinez GD, Cordero-Mora JL, Figueroa-Velasco JL, Ayala-Monter MA, Crosby-Galván MM. Addition of calcium propionate to finishing lamb diets. Veterinaria México OA. 2018;5(4). doi: 10.22201/ fmvz.24486760e.2018.4.470 


\section{Introduction}

Due to a constant increase in grain prices and to competition with sectors such as biofuel production or use for human consumption, it is necessary to find alternatives to partially replace the employ of grains in finishing animal rations. Calcium (Ca) propionate is mainly used as a preservative for animal feeds. It also has the potential to be added as an additive in sheep diets, ${ }^{1,2}$ since propionate is the most important gluconeogenic precursor for ruminants, and can improve the flow of glucose in lambs. ${ }^{3}$ In addition, supplementation of Ca propionate improves insulin action on glucose metabolism ${ }^{4}$ involved in fat deposition ${ }^{5}$ and muscle growth. ${ }^{1}$ However, there is a physiological limit to Ca propionate conversion to glucose ${ }^{7}$, and it should be added to ruminant diets in low doses due to its hypophagic effect. 6

Ca propionate has been used as an energy substrate in lamb diets in a dose of up to $20 \mathrm{~g} \mathrm{~kg}^{-1}$ DM without adverse effects on productive variables or rumen fermentation. ${ }^{1,2}$ In fact, its use in steers improved rumen fermentation and feed digestibility, which could be a further benefit for its use as a nutrient for animal growth. In previous studies with feedlot lamb diets 1,2 researchers have discussed the difference between expected and observed gain in relation to the energetic value of Ca propionate.

There are a few reports that specify the energy values of Ca propionate ${ }^{9,}$ 6, 10 which can be used as a reference for diet formulation. However, animal response is required to accurately estimate the energy value, which should be based on increasing concentrations of Ca propionate. If the response is linear, a constant energy value can be considered, whereas if there is a quadratic effect (associative effects), the energetic value should be a function of the concentration of inclusion. Therefore, the objective of this study was to evaluate the effect of addition of 4 concentrations of Ca propionate to finishing diets of lambs on animal performance, rumen fermentation and blood glucose concentration.

\section{Material and methods}

The experimental procedures were performed according to the International Guidelines for the use of animals in Biomedical Research, ${ }^{11}$ and complied with the official Mexican norm ${ }^{12}$ for care and use of laboratory animals. The study was conducted in the sheep facilities of the Experimental Farm at the Colegio de Postgraduados,

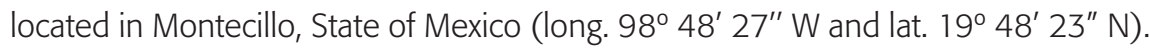
The region is semi-arid, located at a mean altitude of 2,241 $\mathrm{m}$, and has a temperate climate with a mean annual temperature of $15.9^{\circ} \mathrm{C}$, infrequent frosts and a mean annual rainfall of $686 \mathrm{~mm} .^{13}$

\section{Animals and diets}

Thirty two male Hampshire $\times$ Suffolk lambs with an initial BW of $23.8 \pm 1.13 \mathrm{~kg}$ were included. Animals were housed in individual pens equipped with an exclusive feeder and an individual nipple drinker. Lambs were dewormed (Closantel, $20 \mathrm{mg} \mathrm{kg}^{-1}$ animal $^{-1}$ ) and vaccinated (Bobact ${ }^{\circledR} 8,2.0 \mathrm{ml}$ animal ${ }^{-1}$ ) before the start of the study. Food was offered at 8:00 $\mathrm{h}$ and 15:00 h daily. Both food and water were provided ad libitum. The animals had a $10 \mathrm{~d}$ adaptation period to diets. 
Table 1. Experimental diets for lambs fed different concentrations of calcium propionate

\begin{tabular}{|c|c|c|c|c|}
\hline & \multicolumn{4}{|c|}{ Calcium propionate $\mathrm{g} \mathrm{kg}^{-1} \mathrm{DM}$} \\
\hline Ingredient (\%) & 0 & 10 & 20 & 30 \\
\hline Corn grain & 57.49 & 54.73 & 51.63 & 48.92 \\
\hline Soybean meal & 9.00 & 10.61 & 12.54 & 14.00 \\
\hline Cane molasses & 5.00 & 5.00 & 5.00 & 5.00 \\
\hline Calcium propionate & 0.00 & 1.00 & 2.00 & 3.00 \\
\hline Alfalfa hay & 26.80 & 20.07 & 11.93 & 6.24 \\
\hline Oat straw & 0.20 & 6.93 & 15.07 & 20.76 \\
\hline Calcium carbonate & 0.05 & 0.22 & 0.43 & 0.52 \\
\hline Calcium orthophosphate & 0.46 & 0.43 & 0.40 & 0.55 \\
\hline Mineral premix ${ }^{\dagger}$ & 1.00 & 1.00 & 1.00 & 1.00 \\
\hline \multicolumn{5}{|c|}{ Calculated nutrient composition (DM basis) } \\
\hline Metabolizable energy (Mcal kg-1) & 2.50 & 2.50 & 2.50 & 2.50 \\
\hline CPI (\%) & 14.00 & 14.00 & 14.00 & 14.00 \\
\hline UIP§ (\%) & 5.60 & 5.64 & 5.70 & 5.71 \\
\hline Calcium (\%) & 0.69 & 0.69 & 0.69 & 0.70 \\
\hline Phosphorus (\%) & 0.50 & 0.50 & 0.50 & 0.50 \\
\hline ADF $(\%)$ & 12.36 & 12.70 & 13.04 & 13.21 \\
\hline \multicolumn{5}{|c|}{ Determined nutrient composition (DM basis) } \\
\hline CP (\%) & 13.85 & 13.96 & 13.79 & 13.98 \\
\hline Calcium (\%) & 0.70 & 0.72 & 0.69 & 0.75 \\
\hline Phosphorus (\%) & 0.43 & 0.45 & 0.42 & 0.48 \\
\hline ADF (\%) & 13.15 & 13.26 & 13.54 & 13.70 \\
\hline
\end{tabular}

${ }^{\dagger}$ Mineral premix: Phosphorus $17.5 \mathrm{~g} / 100 \mathrm{~g}$, Calcium $6.5 \mathrm{~g} / 100 \mathrm{~g}$, Sodium $6.5 \mathrm{~g} / 100 \mathrm{~g}$, Sulfur $2 \mathrm{~g} / 100 \mathrm{~g}$. ${ }^{1} \mathrm{CP}$ : crude protein. §UIP: rumen-undegradable protein. ${ }^{\mathrm{P}}$ ADF, acid detergent fibre.

The experimental phase lasted for $42 \mathrm{~d}$. Treatments consisted of four different added concentrations of Ca propionate to diets (dry basis): 0, 10, 20 and $30 \mathrm{~g} \mathrm{~kg}^{-1}$ DM (Propical ${ }^{\circledR}$, Dresen S. A. de C. V. Queretaro, México). Rations were formulated for a daily gain of $300 \mathrm{~g}$ d. Particular diet composition is presented in Table $1{ }^{1} .{ }^{14}$

\section{Growth assay}

Recorded variables were: average daily feed intake, average daily gain (ADG), feed: gain ratio (FGR) and final body weight (FBW). Backfat thickness and chop area were measured between the 12th and 13th ribs using a Sonovet 600 real time ultrasound ${ }^{15}$ (Medison, Inc., Cypress, California, USA) fitted with a 7.5 Mhz transducer on days 1 and 42 of the study.

\section{Chemical analysis}

Diet crude protein content was determined by the macro kjeldahl method. ${ }^{16}$ Calcium and phosphorus levels were measured by atomic absorption spectrophotometry ${ }^{17}$ with a Perkin Elmer 4000 Model (Series Lambda 2, Perkin Elmer Inc., 
Norwalk, CT, USA). Acid detergent fiber was quantified by the Van Soest et al. ${ }^{18}$ procedure. Blood $(5 \mathrm{~mL})$ was collected on days 1 and 42 using vacutainer tubes without anticoagulant, and immediately placed under refrigeration $\left(4^{\circ} \mathrm{C}\right)$. Samples were centrifuged (Sigma 2-16k, Germany) at $3500 \mathrm{~g} \times 20$ min to obtain blood serum, which was stored in Eppendorf tubes and kept in a freezer (MDF-436 Sanyo, USA) at $-20{ }^{\circ} \mathrm{C}$ until glucose determination. ${ }^{19}$

\section{Rumen fermentation}

Rumen fluid (50 mL) was extracted at 0800 hours with an esophageal tube, on day 42 of the trial (from animals fasted for $16 \mathrm{~h}$ ). Rumen fluid was collected in an Erlenmeyer flask, immediately filtered with a double layer of gauze and transferred into a $100 \mathrm{~mL}$ beaker. A portable potentiometer was used to measure $\mathrm{pH}$ (Orion, mod A210, USA). Four $\mathrm{mL}$ of rumen fluid were then placed in a test tube with $1 \mathrm{~mL}$ of metaphosphoric acid $(25 \%)$ and stored in a freezer $\left(-20^{\circ} \mathrm{C}\right)$ for further analyses. The $\mathrm{N}-\mathrm{NH}_{3}$ concentrations were determined following the McCullough 20 procedure with a spectrophotometer (Cary 1-E Varian; Perkin Elmer, Model Lamda-40, USA) at $630 \mathrm{~nm}$. Volatile fatty acid content (VFA) wasdetermined by gas chromatography ${ }^{21}$ using a Perkin Claurus Elmer 500, with automatic-sampler.

\section{Statistical analyses}

Data were analyzed using the GLM procedure 22 for a completely randomized design, with four treatments and eight replicates, considering each lamb as an experimental unit. Shapiro-Wilk and Levene's tests were used to verify normal distribution and variance homogeneity of data. Orthogonal contrasts were used to test linear or quadratic effects of Ca propionate concentrations in response variables of interest $(P \leq 0.05)$., The best fitted model was determined by the smallest $P$ value and the largest coefficient of determination $\left(R^{2}\right)$. Initial body weight was used as a covariate. For quadratic responses, the optimum Ca propionate concentration was estimated by linearization of the Gamma function. ${ }^{23}$

\section{Results and discussion Growth assay (Table 2)}

The average daily feed intake was not affected by the addition of Ca propionate to the diet $(P>0.05)$. The FBW and ADG showed a quadratic response $(P<0.01)$, estimating that the optimal added Ca propionate concentration for the enhancement of both of these performance variables is $13.77 \mathrm{~g} \mathrm{~kg}^{-1}$ (ADG $=0.2298235$ $+0.0069876 *$ Ca propionate $-0.0002538 *$ Ca propionate ${ }^{2}+0.0025842 *$ IBW, $R^{2}=0.36 ; F B W=9.2194604+0.2799271 *$ Ca propionate $-0.0101639 *$ Ca propionate $\left.^{2}+1.1020400 * \mid B W, R^{2}=0.56\right)$. The FGR ratio also showed a quadratic response $(\mathrm{P}<0.01)$ to Ca propionate $\left(\mathrm{F}: \mathrm{G}=2.2492769-0.1087659^{*}\right.$ Ca propionate $+0.0037852 *$ Ca propionate $\left.{ }^{2}+0.1113845^{*} \mid \mathrm{BW} ; \mathrm{R}^{2}=0.37\right)$. The chop area and backfat thickness were not affected by the concentration of Ca propionate in the diet $(P>0.05)$. 
Table 2. Performance of finishing lambs fed with different concentrations of calcium propionate

\begin{tabular}{|c|c|c|c|c|c|c|c|}
\hline & \multicolumn{4}{|c|}{ Calcium propionate $\left(\mathbf{g ~ k g}^{-1}\right)$} & \multirow[t]{2}{*}{ SEMP } & \multicolumn{2}{|c|}{ Pvalue } \\
\hline & 0 & 10 & 20 & 30 & & Linear & Quadratic \\
\hline Initial body weight (kg) & 23.33 & 23.83 & 23.82 & 24.29 & 0.40 & - & - \\
\hline Final body weight (kg) & 34.93 & 37.28 & 36.99 & 35.24 & 0.69 & 0.41 & $* *$ \\
\hline $\operatorname{ADG}^{\dagger}\left(\mathrm{g} \mathrm{d}^{-1}\right)$ & 0.29 & 0.34 & 0.33 & 0.27 & 0.01 & 0.41 & $* *$ \\
\hline $\operatorname{ADF|}\left(\mathrm{g} \mathrm{d}^{-1}\right)$ & 1.40 & 1.39 & 1.38 & 1.37 & 0.04 & 0.12 & 0.92 \\
\hline FGR§ & 4.86 & 4.15 & 4.28 & 5.08 & 0.21 & 0.67 & $* *$ \\
\hline Chop area $\left(\mathrm{mm}^{2}\right)$ & 993.88 & 985.13 & 998.38 & 985.13 & 27.35 & 0.86 & 0.94 \\
\hline Backfat thickness (mm) & 3.00 & 3.13 & 3.13 & 3.00 & 0.09 & 0.89 & 0.17 \\
\hline
\end{tabular}

${ }^{\dagger}$ ADG: average daily gain; ${ }^{\top}$ ADFI: daily feed intake; $\S$ FGR: feed: gain ratio; SEM: standard error of the mean; * $(P \leq 0.05) ; * *(P \leq 0.01)$

Previous studies have reported that the addition of up to $20 \mathrm{~g} \mathrm{~kg}^{-1} \mathrm{DM}$ of Ca propionate to feedlot rations of lambs did not decrease feed intake.1, 2, 24 In contrast, the use of Ca propionate in cattle seems to have a hypophagic effect ${ }^{25}, 26$ when consumed in concentrations of over 12 moles per day ${ }^{-1}{ }^{2}$ This suggests that the addition of Ca propionate may cause hypophagic effects when added in amounts greater than $30 \mathrm{~g} \mathrm{~kg}^{-1} \mathrm{DM}$. Nonetheless, concentrations over $30 \mathrm{~g} \mathrm{~kg}^{-1}$ DM were not included in this study.

Previous work has shown that 10 or $20 \mathrm{~g} \mathrm{~kg}^{-1} \mathrm{DM}$ of Ca propionate added to finishing diets of lambs did not modify ADG or FGR. ${ }^{1}{ }^{2}$ However, supply of propionate directly into the rumen, or use of dietary sources that increase propionate production in improve average daily gain in dairy cows. ${ }^{26,27}$

Average daily gain measurements in this study showed that the energy value of Ca propionate is not constant and that it has a curvilinear nature similar to that observed in cows by Rigout et al. ${ }^{9}$ Based on the system equations net energy of California ${ }^{28}$ we can estimate a ME value for Ca propionate of $4.8 \mathrm{Mcal} \mathrm{kg}^{-1} \mathrm{DM}$ when it is added to the diet in a concentration of $10 \mathrm{~g} \mathrm{~kg}^{-1} \mathrm{DM}$. Conversely, when it is included at higher concentrations, its estimated ME value can be reduced by half and or energy may not be produced at all. The ME value estimated in this study is higher than the one reported by Mendoza-Martinez et al. ${ }^{2}$ of $3.766 \mathrm{Mcal} \mathrm{kg}^{-1}$, which may be due to the fact that the value is not constant.

Lee-Rangel et al. ${ }^{1}$ and Mendoza-Martinez et al. ${ }^{2}$ observed that the addition of Ca propionate in finishing diets of lambs did not alter chop area or carcass weight. However, Mendoza-Martinez et al. ${ }^{2}$ observed a reduction of oleic acid and an increase of linolenic acid. Bbut backfat thickness was not measured in their experiment, but authors reported that Ca propionate did modify fatty acid composition of meat.

\section{Rumen fermentation and blood glucose concentrations (Table 3)}

The addition of $\mathrm{Ca}$ propionate to the diet did not affect $\mathrm{pH}$, total VFA, or $\mathrm{N}$ - ammonia concentrations in rumen fluid $(\mathrm{P}>0.05)$. Similarly, levels of acetate and butyrate were not affected $(P>0.05)$. However, rumen fluid propionate concentrations showed a quadratic response $(P<0.05)$, reaching its highest level with an estimated Ca propionate concentration of $20.34 \mathrm{~g} \mathrm{~kg}^{-1} \mathrm{DM}$ 
Table 3. Rumen fermentation pattern and blood glucose concentrations in finishing lambs fed with diets containing different concentrations of calcium propionate

\begin{tabular}{|c|c|c|c|c|c|c|c|}
\hline & \multicolumn{4}{|c|}{ Calcium propionate $\left(\mathrm{g} \mathrm{kg}^{-1}\right)$} & \multirow{2}{*}{ SEMP } & \multicolumn{2}{|c|}{ P value } \\
\hline & 0 & 10 & 20 & 30 & & Linear & Quadratic \\
\hline Serum glucose $\left(\mathrm{mg} \mathrm{dL}^{-1}\right)$ & 60.75 & 71.00 & 68.25 & 67.25 & 1.97 & 0.84 & $* *$ \\
\hline Rumen pH & 7.15 & 7.35 & 7.22 & 7.30 & 0.05 & 0.43 & 0.22 \\
\hline Ammonia-N (mg dL $\left.{ }^{-1}\right)$ & 4.06 & 3.26 & 4.43 & 3.98 & 0.93 & 0.99 & 0.96 \\
\hline Total VFA $\left(\mathrm{mmol} \mathrm{L}^{-1}\right)$ & 18.96 & 21.19 & 18.20 & 20.07 & 1.82 & 0.91 & 0.86 \\
\hline \multicolumn{8}{|l|}{$\operatorname{VFA}^{\dagger}\left(\mathrm{mmol} \mathrm{mmol}{ }^{-1}\right)$} \\
\hline Acetate & 0.63 & 0.61 & 0.57 & 0.62 & 0.017 & 0.25 & 0.19 \\
\hline Propionate & 0.16 & 0.20 & 0.22 & 0.21 & 0.01 & $*$ & * \\
\hline Butyrate & 0.14 & 0.12 & 0.12 & 0.11 & 0.01 & 0.19 & 0.26 \\
\hline
\end{tabular}

(Propionate $=0.1802155+0.0062904 *$ Ca propionate $-0.0001546 *$ Ca propionate $\left.^{2}+0.0009891 * \mid B W ; R^{2}=0.49\right)$. Blood glucose levels also showed a quadratic response $(P<0.01)$ to added dietary Ca propionate with the highest response reached with $15.14 \mathrm{~g} \mathrm{~kg}^{-1}$ (Glucose $=61.0171329+1.7246650 *$ Ca propionate - 0.0569418*Ca propionate $\left.{ }^{2}+0.0411237 * I B W, R^{2}=0.78\right)$.

Quigley and Heitmann ${ }^{29}$ did not find changes on rumen fluid $\mathrm{pH}$ after Ca propionate infusions in sheep. Similarly, Lee-Rangel et al. ${ }^{1}$ and Mendoza-Martínez et al. ${ }^{2}$ did not observe rumen fluid pH or VFA alterations when adding Ca propionate to lamb diets.

In a previous study Sanchez et al. ${ }^{30}$ found that Ca propionate supplementation increased rumen propionate and reduced the acetate:propionate ratio without having an effect on $\mathrm{pH}$ or on total VFA in heifers. Moreover, an increase in propionate enhances weight gain in heifers 27 as it relates with an increase of blood glucose levels.

In a study conducted by Majdoub et al. ${ }^{24}$ propionate supplementation to grazing lambs increased glucose production and lactate concentrations, the latter of which can also be used for additional glucose synthesis. These changes can be associated with an increase in insulin secretion. ${ }^{4,24}$ Accordingly, other studies with dairy cattle have shown that propionate, either infused or added to the diet, increases blood glucose concentrations. ${ }^{26,31}$

\section{Implications}

The increase of propionate and glucose concentrations following Ca propionate administration to finishing diets of lambs $\left(13.77 \mathrm{~g} \mathrm{~kg}^{-1}\right.$ ), improves average daily gain and FGR. However, when Ca propionate is supplemented at higher doses (20 $\mathrm{g} \mathrm{kg}^{-1}$ ) the benefits of its use are reduced. Economic analyses may drive the use of Ca propionate in farms because even if the cost per $\mathrm{kg}$ ( $\$ 5.0$ US dollars $\mathrm{kg}^{-1}$ ) surpasses that of the cost of grain ( $1 \mathrm{~kg}$ corn $\$ 0.25$ US dollars), the results show that $10 \mathrm{~g} \mathrm{~kg}^{-1}$ of Ca propionate can replace $150 \mathrm{~g} \mathrm{~kg}^{-1}$ of grains without affecting lamb performance. ${ }^{1}$ 


\section{Conclusion}

Ca propionate can be added as an energy source in finishing lamb diets in concentrations of up to $30 \mathrm{~g} \mathrm{~kg}^{-1} \mathrm{DM}$, without affecting lamb performance, carcass traits or rumen fermentation. According to this study, the recommended quantity to add to lamb finishing diets is $13.77 \mathrm{~g} \mathrm{~kg}^{-1} \mathrm{DM}$, based on improvement of performance variables. This dose also increased rumen propionate and serum glucose concentrations.

\section{Conflicts of interest}

Authors declare that there is no conflict of interest regarding publication of this article.

\section{Author contributions}

Jose Alfredo Martinez Aispuro: experimental work; laboratory work and statistical analysis of data. Drafted manuscript.

María Teresa Sánchez-Torres: designed, directed and supervised the research; revised final manuscript.

German David Mendoza Martinez: revised research proposal and final manuscript.

José Luis Cordero-Mora: collaborated with proposal draft, experimental work; supervised health status of lambs; obtained samples and data; revised final version of manuscript.

José Luis Figueroa-Velasco: revised research proposal, final version of proposal and final manuscript.

Marco Antonio Ayala Monter: experimental design; supervision of experimental protocol; supervision and support to experimental and data analysis.

Maria Magdalena Crosby Galvan: laboratory work. Revised research proposal and final manuscript.

\section{References}

1. Lee-Rangel HA, Mendoza GD, González SS. Effect of calcium propionate and sorghum level on lamb performance. Anim Feed Sci Technol. 2012;177:237-41.

2. Mendoza-Martínez GD, Pinos-Rodríguez JM, Lee-Rangel HA, Hernández-García PA, Rojo-Rubio R, Relling A. Effects of dietary calcium propionate on growth performance and carcass characteristics of finishing lambs. Anim Prod Sci. 2015;56:1194-8.

3. Van Houtert MFJ, Nolan JV, Leng RA. Protein, acetate and propionate for roughage-fed lambs. 2. Nutrient kinetics. Anim Sci. 1993;56:369-78.

4. Sano H, Fujita T. Effect of supplemental calcium propionate on insulin action to blood glucose metabolism in adult sheep. Reprod Nutr Dev. 2006;46:9-18.

5. Berthelot $V$, Bas $P$, Schmidely $P$, Duvaux-Ponter $C$. Effect of dietary propionate on intake patterns and fatty acid composition of adipose tissues in lambs. Small Rumin Res. 2001;40:29-39.

6. Oba M, Allen MS. Extent of hypophagia caused by propionate infusion is related to plasma glucose concentration in lactating dairy cows. J Nutr. 2003;133:1005-12. 
7. Steel JW, Leng RA. Effects of plane of nutrition and pregnancy on gluconeogenesis in sheep. 2. Synthesis of glucose from ruminal propionate. $\mathrm{Br} J$ Nutr. 1973;30:475-89.

8. Liu Q, Wang C, Guo G, Yang WZ, Dong KH, Huang YX, et al. Effects of calcium propionate on rumen fermentation, urinary excretion of purine derivatives and feed digestibility in steers. J Agric Sci. 2009;147:201-9.

9. Rigout $\mathrm{S}$, Hurtaud $\mathrm{C}$, Lemosquet $\mathrm{S}$, Bach $\mathrm{A}$, Rulquin $\mathrm{H}$. Lactational effect of propionic acid and duodenal glucose in cows. J Dairy Sci. 2003;86:243-53.

10. De Blas C, Mateos GC, García- Rebollar P, Fundación Española para el Desarrollo de la Nutrición Animal (FEDNA). Tablas FEDNA de composición y valor nutritivo de alimentos para la fabricación de piensos compuestos. $3^{a}$ ed. Madrid: Fundación Española para el Desarrollo de la Nutrición Animal; 2010.

11. Council for International Organizations of Medical Sciences. International Guiding Principles for Biomedical Research Involving Animals; 2012 [cited 2017 Jan 23]. Available from: http://www.cioms

12. Secretaría de Gobernación. [NOM-062-ZOO] Norma Oficial Mexicana. Especificaciones técnicas para la producción, cuidado y uso de los animales de laboratorio. Ciudad de México: Diario Oficial de la Federación; 1999.

13. García E. Modificaciones al sistema de clasificación de Köppen. $4^{a}$ ed. Ciudad de México: Instituto de Geografía, UNAM; 1988.

14. National Research Council (NRC). Nutrient requirements of small ruminants. 7th ed. Washington, DC: National Academy Press; 2007.

15. Silva SR, Gomes MJ, Días-da-Silva A, Gil LF, Azevedo JM. Estimation in vivo of the body and carcass chemical composition of growing lambs by real-time ultrasonography. J Anim Sci. 2005; 83:350-357.

16. Association of Official Analytical Chemists International. Official methods of analysis. 18th ed. Washington DC: Association of Official Analytical Chemists International; 2005.

17. Karl RF, McDowell LR, Miles PH, Wilkinson NS, Funk JD, Conrad JH. Methods of Mineral Analysis of Plant and Animal Tissues. 2nd ed. Gainesville, FL: University of Florida; 1979.

18. Van Soest PJ, Robertson JB, Lewis BA. Methods for dietary fibre, neutral detergent fibre, and nonstarch carboydrates in relation to animal nutrition. J Dairy Sci. 1991;74:3583-3597.

19. Trinder P. Determination of glucose in blood using glucose oxidase with an alternative oxygen acceptor. Ann Clin Biochem. 1969;6:24-7.

20. McCullough $\mathrm{H}$. The determination of ammonia in whole blood by direct colorimetric method. Clin Chim Acta. 1967;17:297-304.

21. Erwin ES, Marco GJ, Emery E. Volatile fatty acid analysis of blood and rumen fluid by gas chromatography. J Dairy Sci. 1961;44:1768-71.

22. SAS Institute. The SAS System, release 8.2 for Windows. Cary, North Carolina: SAS Institute; 2009.

23. Herrera HJG, Barreras AS. Análisis estadístico de experimentos pecuarios: Manual de Procedimientos (Aplicaciones del programa SAS). $2^{\mathrm{a}}$ ed. Texcoco, Estado de México: Colegio de Posgraduados; 2005.

24. Majdoub L, Vermorel M, Ortigues-Marty I. Grass based diet and barley supplementation: partition of energy-yielding nutrients among splanchnic tissues and hindlimb in finishing lambs. J Anim Sci. 2003;81:1068-79. 
25. Bradford BJ, Allen MS. Phlorizin administration does not attenuate hypophagia induced by intraruminal propionate infusion in lactating dairy cattle. J Nutr. 2007; 137:326-30.

26. Liu Q, Wang C, Yang WZ, Guo G, Yang XM, He DC, et al. Effects of calcium propionate supplementation on lactation performance, energy balance and blood metabolites in early lactation dairy cows. J Anim Physiol Anim Nutr. 2010;94:605-14.

27. Whitney MB, Hess BW, Burgwald-Balstad LA, Sayer JL, Tsopito CM, Talbott CT, et al. Effects of supplemental soybean oil level on in vitro digestion and performance of prepubertal beef heifers. J Anim Sci. 2000;78:504-14.

28. Osorio I, Mendoza GD, Plata FX, Martínez JA, Vargas L, Ortega GC. A simulation model to predict body weight gain in lambs fed high-grain diets. Small Rumin Res. 2015;123:246-50.

29. Quigley JD, Heitmann RH. Effects of propionate infusion and dietary energy on dry matter intake in sheep. J Anim Sci. 1991;69:1178-87.

30. Sanchez PH, Tracey LN, Browne-Silva J, Lodge-Ivey SL. Propionibacterium acidipropionici P169 and glucogenic precursors improve rumen fermentation of low-quality forage in beef cattle. J Anim Sci. 2014;92:1738-46.

31. Seal CJ, Parker DS. Effect of intraruminal propionic acid infusion on metabolism of mesenteric and portal-drained viscera in growing steers fed a forage diet: I. Volatile fatty acids glucose and lactate. J Anim Sci. 1994;72:1325-34. 